\title{
Analgesic effect of photobiomodulation after placement of elastomeric separators: randomized controlled clinical trial
}

Efeito analgésico da fotobiomodulação após colocação de separadores elastoméricos: ensaio clínico controlado randomizado

Efecto analgésico de la fotobiomodulación tras la colocación de separadores elastoméricos: ensayo clínico controlado aleatorizado

Tânia Oppido Schalch ORCID: https://orcid.org/0000-0003-1703-4816 Universidade Nove de Julho, Brazil

E-mail: taniaschalch@gmail.com

Tamiris Silva

ORCID: https://orcid.org/0000-0003-2023-4798

Universidade Nove de Julho, Brazil

E-mail: tamiris.slv@hotmail.com

Juliana Maria Altavista Sagretti Gallo

ORCID: https://orcid.org/0000-0003-3466-1715

Universidade Metropolitana de Santos, Brazil

E-mail: jualtavistagallo@gmail.com

Olga Maria Altavista

ORCID: https://orcid.org/0000-0003-1130-6227

Universidade Nove de Julho, Brazil

E-mail: altavista.olgamaria@uni9.pro.br

Alessandro Mello Deana

ORCID: https://orcid.org/0000-0002-0014-6953

Universidade Nove de Julho, Brazil

E-mail: amdeana@gmail.com

Lara Jansiski Motta

ORCID: https://orcid.org/0000-0002-7774-4345

Universidade Nove de Julho, Brazil

E-mail: larajmotta@uni9.pro.br

Kristianne Porta Santos Fernandes

ORCID: https://orcid.org/0000-0001-7156-9286

Universidade Nove de Julho, Brazil

E-mail: kristianneporta@gmail.com

Raquel Agnelli Mesquita-Ferrari

ORCID: https://orcid.org/0000-0001-5142-9526

Universidade Nove de Julho, Brazil

E-mail: raquel.mesquita@gmail.com

Aldo Brugnera Júnior

ORCID: https://orcid.org/0000-0002-8634-743X

Universidade de São Paulo, Brazil

E-mail: aldobrugnera@gmail.com

Anna Carolina Ratto Tempestini Horliana ORCID: https://orcid.org/0000-0003-3476-9064

Universidade Nove de Julho, Brazil

E-mail: annacrth@gmail.com

Sandra Kalil Bussadori

ORCID: https://orcid.org/0000-0002-9853-1138

Universidade Nove de Julho, Brazil

E-mail: sandra.skb@gmail.com 


\begin{abstract}
Objective: Pain resulting from the positioning of elastomeric separators is a strong reason for abandoning orthodontic treatment. So, this study aims to verify the analgesic effects of photobiomodulation (PBM) in participants submitted to orthodontics with elastomeric separators. Methods: Participants were individuals who received separators on the mesial and distal surfaces of the first molars. They were randomly separated into two groups: an experimental group that received photobiomodulation $(\mathrm{PBM})(\mathrm{n}=22)$ and a placebo group $(\mathrm{n}=22)$. After the positioning of the separators, the PBM group received one application of PBM ( $2 \mathrm{~J}$ of energy applied in 20 seconds per point, adding up to $12 \mathrm{~J}$ per molar ( $6 \mathrm{~J}$ on the vestibular surface and $6 \mathrm{~J}$ on the lingual surface) over the cervical portion and the apical third of the tooth. Pain was measured one hour after placement, with the aid of a visual analog scale (VAS). Statistical analysis involved the Mann-Whitney, Fisher's Exact and chi-square tests. Results: Reports of severe pain only occurred in the placebo group. However, a larger percentage of the individuals in the PBM group reported feeling moderate pain compared to this same intensity in the placebo group. No significant differences among groups were found with regards to reports of mild pain and no pain. An association was found between pain and the female sex in both groups. Conclusion: Significant difference was found in severe pain sensitivity when PBM was applied after the positioning of elastomeric separators, favoring the irradiated participants. Thus, PBM may be a useful tool in orthodontic treatment. Clinical Trials Reference Number (www.ClinicalTrials.gov), NCT03939988.
\end{abstract}

Keywords: Pain; Photobiomodulation; Orthodontics; Elastomeric separators.

\title{
Resumo
}

Objetivo: A dor decorrente do posicionamento dos separadores elastoméricos é um forte motivo para o abandono do tratamento ortodôntico. Portanto, esse estudo pretende verificar os efeitos analgésicos da fotobiomodulação (PBM) em participantes submetidos à ortodontia com separadores elastoméricos. Metodologia: Os participantes foram indivíduos que receberam separadores nas superfícies mesial e distal dos primeiros molares. Eles foram separados aleatoriamente em dois grupos: um grupo experimental que recebeu fotobiomodulação (PBM) (n=22) e um grupo placebo $(\mathrm{n}=22)$. Após o posicionamento dos separadores, o grupo PBM recebeu uma aplicação de PBM (2 J de energia aplicada em 20 segundos por ponto, somando $12 \mathrm{~J}$ por molar 6 J na superfície vestibular e 6 J na superfície lingual) sobre a porção cervical e o terço apical do dente. A dor foi mensurada uma hora após a colocação, com auxílio de uma escala visual analógica (EVA). A análise estatística envolveu os testes Mann-Whitney, Exato de Fisher e Qui-quadrado. Resultados: Relatos de dor intensa ocorreu apenas no grupo placebo. No entanto, uma porcentagem maior dos indivíduos do grupo PBM relatou sentir dor moderada em comparação com essa mesma intensidade no grupo placebo. Não foram encontradas diferenças significativas entre os grupos em relação ao relato de dor leve e sem dor. Foi encontrada associação entre dor e sexo feminino em ambos os grupos. Conclusão: Foi encontrada diferença significativa na sensibilidade à dor intensa quando a PBM foi aplicada após o posicionamento dos separadores elastoméricos, favorecendo os participantes irradiados. Assim, a PBM pode ser uma ferramenta útil no tratamento ortodôntico. Número de Referência do Ensaio no Clinical Trials (www.ClinicalTrials.gov), NCT03939988.

Palavras-chave: Dor; Fotobiomodulação; Ortodontia; Separadores elastoméricos.

\section{Resumen}

Objetivo: El dolor resultante de la colocación de separadores elastoméricos es un motivo de peso para abandonar el tratamiento de ortodoncia. Así, este estudio tiene como objetivo verificar los efectos analgésicos de la fotobiomodulación (PBM) en participantes sometidos a ortodoncia con separadores elastoméricos. Métodos: Los participantes fueron individuos que recibieron separadores en las superficies mesial y distal de los primeros molares. Fueron separados aleatoriamente en dos grupos: un grupo experimental que recibió fotobiomodulación $(\mathrm{PBM})(\mathrm{n}=22)$ y un grupo simulado $(\mathrm{n}=22)$. Después de la colocación de los separadores, el grupo PBM recibió una aplicación de PBM (2 J de energía aplicada en 20 segundos por punto, sumando $12 \mathrm{~J}$ por molar (6 J en la superficie vestibular y $6 \mathrm{~J}$ en la superficie lingual) sobre la porción cervical y el tercio apical del diente. El dolor se midió una hora después de la colocación, con la ayuda de una escala analógica visual (EVA). El análisis estadístico involucró las pruebas de MannWhitney, Exacto de Fisher y chi-cuadrado. Resultados: Informes sin embargo, un mayor porcentaje de los individuos del grupo PBM reportaron sentir dolor moderado en comparación con esta misma intensidad en el grupo simulado. Se encontró una asociación entre el dolor y el sexo femenino en ambos grupos. Conclusión: Se encontró diferencia significativa en la sensibilidad al dolor severo. Cuando se aplicó PBM después del posicionamiento de los separadores elastoméricos, favoreciendo los participantes irradiados. Por lo tanto, PBM puede ser una herramienta útil en el tratamiento de ortodoncia. Número de referencia de ensayos clínicos (www.ClinicalTrials.gov), NCT03939988.

Palabras clave: Dolor; Fotobiomodulación; Ortodoncia; Separadores elastoméricos.

\section{Introduction}

The main complaints of orthodontic patients are the prolonged treatment time and pain, which is often underestimated

by orthodontists (Sousa, 2014; Marini, 2015; Dalaie, 2015). Despite recent advances, about 90\% of patients connect 
orthodontics with pain and this is the most frequent factor in the avoidance of treatment (Artés-Ribas, 2013; Eslamian, 2013; Sobouti, 2015). Pain is subjective and its intensity varies depending on one's personal history, sex, age and external factors (Artés-Ribas, 2013).

The sensation of pain originated by the positioning of elastomeric separators during orthodontic treatment is very usual and acute in the first couple of days (Kim, 2013; Almallah, 2016). Forces create zones of compression and tension in the periodontal ligament, followed by inflammatory reactions inducing a cascade of reactions, such as a change in bloodstream and the liberation of chemical mediators, like histamine, serotonin, dopamine, glycine, prostaglandins, substance P and cytokines, resulting in hyperalgesia (Ren, 2015; Almallah, 2016; Farias, 2016). Prostaglandins, substance P, encephalin, leukotrienes, bradykinins and histaminas are the major mediators in this process, as these substances sensitize nerve endings, increasing inflammation and pain (Marini, 2015; Ren, 2015; Bayani, 2016).

Patients with a high pain index tend to use pharmacological agents, such as analgesics and antiinflammatories. However, such medications have systemic side effects, such as allergy, peptic ulcer and congestive heart problems, and can also interfere in orthodontic movement by affecting the mechanism of action of osteoclasts, thereby further extending treatment (Artés-Ribas, 2013; Sobouti, 2015; Ren, 2015; Mohammad-Hoseyni, 2015; Almallah, 2016; de Sousa, 2018).

Novel hypothesis are being researched and low-level laser therapy has been proven effective because of the therapeutic effects of photobiomodulation (PBM). According to studies, this is an effective, easy-to-administer, simple, painless therapeutic modality with no side effects and few contraindications (Kim, 2013; Sousa, 2014). Besides reductions in pain and inflammation, the biological responses of PBM include the induction of cell proliferation, acceleration of the healing process, assistance in neurological regeneration, the promotion of vascular and lymphatic microcirculation and modulation of the immune system (Huany, 2013; Basso, 2016; Nadhreen, 2019).

The analgesic and anti-inflammatory properties of PBM are related to the reactivation of enzymes directed at paininducing factors, the inhibition of nerve depolarization (C fibers), cyclooxygenase 2 (COX-2), the production of ATP, the degradation of bradykinin as well as reductions in inflammatory cytokines and prostaglandins. PBM also promotes an increase in the activity of cell receptors responsible for the induction of the production of endorphins and the action potential of neurons (Sobouti, 2015; Mohammad-Hoseyni, 2015).

According to the literature, both red and infrared lasers have analgesic action. However, there are no clear, welldefined parameters due to the heterogeneity found in literature, with the use of different light sources, irradiation parameters and methods. It is therefore of considerable importance to establish a clinical protocol that supports the analgesic effects of PBM (Ren, 2015).

The objetive of the present study was to verify the analgesic effects of one of PBM in orthodontic patients submitted to the positioning of elastomeric separators.

\section{Methodology}

\section{Type of study}

The present randomized and controlled, clinical trial was reported following guidelines of the Consolidated Standards of Reporting Trials (CONSORT) and was conducted with patients at the dentistry clinic of Universidade Nove de Julho, São Paulo, Brazil. The project was submitted to Universidade Nove de Julho's ethics committee, in accordance with Resolution 466/2012 of the National Board of Health. The trial was conducted in accordance with the 1964 Declaration of Helsinki and its later amendments. All participants (or their guardians) who were included in the study signed a free informed consent term. 


\section{Registration of study}

This study received approval from the ethics committee of Universidade Nove de Julho (certificate number: 13694419.1.0000.5511) and was registered with ClinicalTrial.gov at https://clinicaltrials.gov/ct2/show/NCT03939988.

\section{Sample calculation}

The sample size calculation was determined, based on the results of a preceding study by Qamruddin, 2016 and using the $\mathrm{G}^{*}$ Power program, version 3.1.9.2. For a test power higher than $80 \%$, considering a $5 \%$ significance level and size effect higher than 0.60, 36 individuals would be necessary, per group (total: 72), to detect a difference between groups.

$$
d=\frac{\text { largest }- \text { smallest }}{\left(\frac{\sigma}{\sqrt{n}}\right)^{2}}=\frac{5.04-1.86}{\left(\frac{3.24}{\sqrt{2}}\right)^{2}}=0.60
$$

However, we were only able to include 42 individuals. The participants were male and female, with at least 11 years of age, who were being submitted to orthodontic treatment at the dentistry clinic of Universidade Nove de Julho, São Paulo. The volunteers were randomly separated in two groups: an experimental group with 22 individuals and a placebo group with 22 individuals.

\section{Randomization of participants}

Randomization was performed using a computer-generated sequence (Excel 2007). Sealed envelopes contained either the letter "A" (PBM group) or "B" (placebo group). The participants who received the letter "A" were irradiated with infrared laser immediately after the positioning of the elastomeric separators. Participants who received the letter "B" were submitted to the same procedure, but the emission of irradiation was simulated..$^{10}$ The participants were not aware of the group to which they belonged.

\section{Inclusion criteria}

Individuals of either sex with at least 11 years of age beginning orthodontic treatment for the first time were included in the study. We confirmed normal periodontal status in a previous exam, involving probing of the gingival sulcus. Patients with sound first molars, that presented interproximal contacts between the second molar and the second premolar, in permanent dentition, and who had not used anti-inflammatory and/or analgesic agents in the preceding four days (Farias, 2016) were included.

\section{Exclusion criteria}

Individuals with systemic diseases, periodontal disease, gingival disease, pregnant women, and individuals who habitually took medications for pain or inflammation were excluded from the study.

\section{Operational plan}

Participants received explanations regarding the aims of the trial and signed an informed consent term (those over 18 years of age and guardians of those under 18 years of age) and/or a statement of assent (minors) (Farias, 2016).

The individuals were randomly allocated to two groups by choosing between two envelopes (one with the letter "A" $[\mathrm{PBM}]$ and one with the letter "B" [placebo]). The participants were blind to the correspondence of the letters. The PBM group was submitted to active infrared laser irradiation and the placebo group had simulated irradiation with the laser device 
switched off but emitting a sound to give the appearance of being activated. The researcher inserted the elastomeric separators (4.0 $\mathrm{mm}$ in diameter, reference 60.04.200, Morelli Ortodontia) with the aid of dental floss. The separators were placed at the interproximal contacts between the second premolar and the first molar, and between the first molar and the second molar. The participants then received a single session of PBM (active or placebo). The placement of the separators and administration of PBM were performed by the same researcher. The researcher and the participants wore protective goggles during the irradiation procedure (Farias, 2016).

Irradiation was applied to three points on the vestibular face and three points on the lingual face of the first molar: interproximal papillae of mesial and distal cervical thirds and apical third of the roots.

\section{Photobiomodulation}

A Ga-Al-As laser (Therapy XT, DMC, São Carlos, Brazil) was used, with $100 \mathrm{~mW}$ power, tip diameter of $600 \mu \mathrm{m}$. The laser had two optical fibers - each with a continuous wavelength of $808 \mathrm{~nm}$ (infrared) and $660 \mathrm{~nm}$ (red). Participants in the PBM group received the infrared laser (wavelength: $808 \mathrm{~nm}$ ) in continuous mode.

The tip of the device was positioned perpendicularly to the mucosa (without pressing) for the application in the active group and simulated laser in the placebo group (Figure 1). The parameters in the active PBM group were of $2 \mathrm{~J}$ of energy applied in 20 seconds per point, adding up to $12 \mathrm{~J}$ per molar ( $6 \mathrm{~J}$ on the vestibular surface and $6 \mathrm{~J}$ on the lingual surface). The parameters, described in Table 1, were selected based on a previous study (Sousa, 2014). An hour after the positioning of the orthodontic separators and application of PBM (active or placebo), the patients reported their perceptions of pain on a numeric visual analog scale (VAS) (Figure 2) at predetermined intervals. The 11-point scale ranges from 0 (absence of pain) to 10 (intolerable pain). Participants were instructed not to take any medications during the trial.

Figure 1: Application of infrared laser.

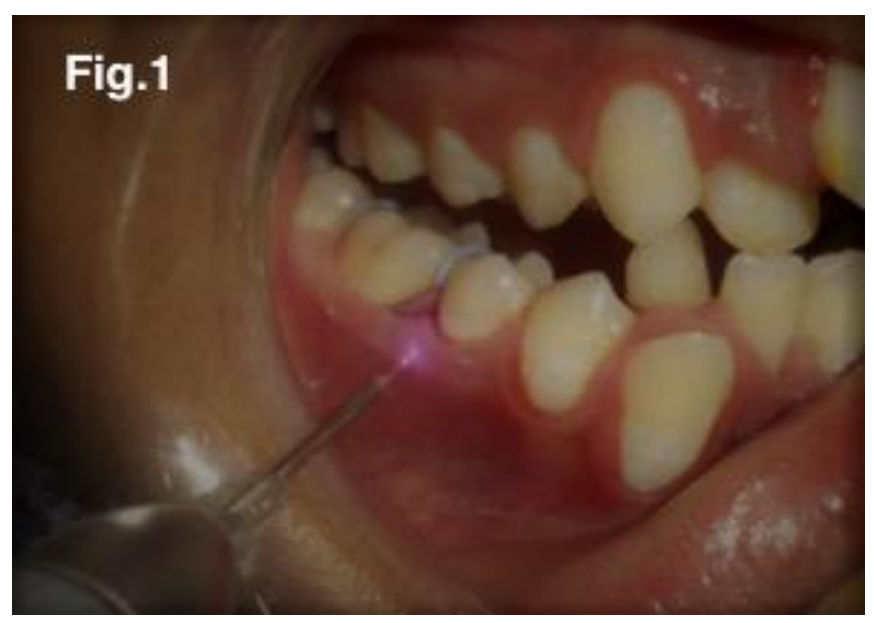

Source: personal archive. 
Figure 2: Numeric Visual Analog Scale.

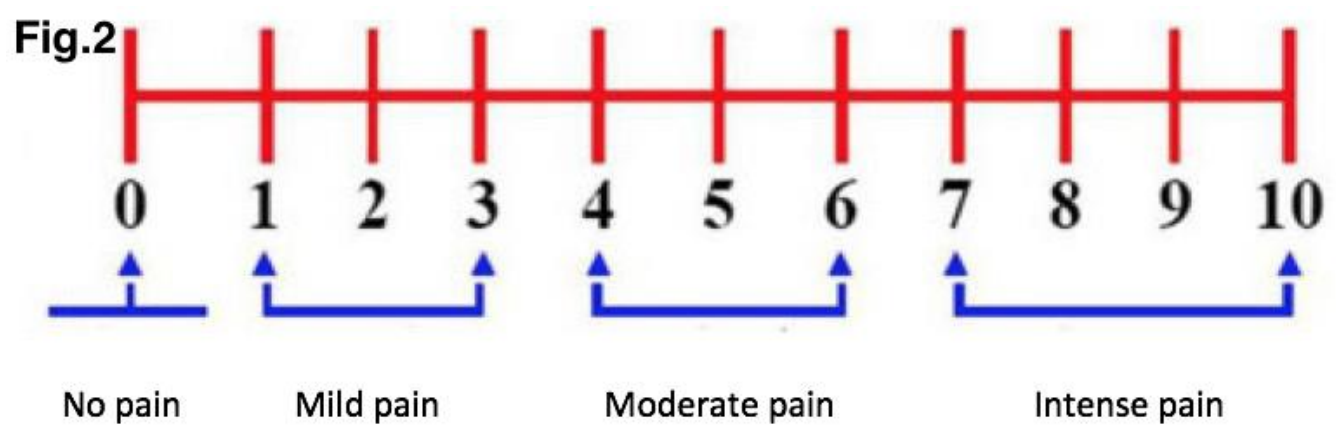

Source: personal archive.

Table 1: Dosimetric parameters.

\begin{tabular}{|l|l|}
\hline Wavelength & $808 \mathrm{~nm}$ \\
\hline Spectral width (FWHM) & $2 \mathrm{~nm}$ \\
\hline Operating mode & Continuous \\
\hline Polarization & Random \\
\hline Bean profile & Multimodal \\
\hline Area at target & $0.002826 \mathrm{~cm}^{2}$ \\
\hline Irradiance at target & $35385 \mathrm{~mW} / \mathrm{cm}^{2}$ \\
\hline Radiant exposure & $707.4 \mathrm{~J} / \mathrm{cm}^{2}$ \\
\hline Irradiated area & $0.01695 \mathrm{~cm}^{2}$ \\
\hline Radiant power & $100 \mathrm{~mW}$ \\
\hline Exposure time & $20 \mathrm{~s} \mathrm{per} \mathrm{point}$ \\
\hline Aperture diameter & $600 \mu \mathrm{m}$ \\
\hline Irradiance at aperture & $35385 \mathrm{~mW} / \mathrm{cm}^{2}$ \\
\hline Radiant energy & $2 \mathrm{~J}$ per point \\
\hline Number of points irradiated & $6-3$ points on vestibular face and 3 points on lingual face \\
\hline Application method & Contact \\
\hline Number of sessions & Single session \\
\hline Total energy irradiated & $12 \mathrm{~J}$ per tooth \\
\hline & Solre: \\
\hline
\end{tabular}

Source: personal archive.

\section{Analysis of cytokine profile of crevicular gingival fluid}

Collection of gingival crevicular fluid was conducted for the evaluation of cytokines. Before and one hour after the positioning of the separators, absorbent paper cones were inserted in the cervical middle third of the vestibular surface of each tooth. Supragingival plaque was removed before this procedure. The teeth were isolated with relative isolation. The insertion was performed until encountering mild resistance and the cones were kept in position for 30 seconds. The volume of the gingival crevicular fluid was calculated by the difference in the weight of the paper cone before and after the placement of the separators, at a proportion of $1 \mathrm{~g} / \mathrm{ml}$. The samples were put in sterile tubes with $2 \mathrm{ml}$ of phosphate buffer solution (pH 7.4) and stored at $70^{\circ} \mathrm{C}$ for the posterior analysis of IL-1 $\beta$. Cytokine levels were determined by a single researcher, using ELISA interleukin kits and strictly following the manufacturer's instructions (Murakami-Malaquias-Silva, 2020). 


\section{Statistical analysis}

The data were organized using Microsoft Excel. Frequency and percentage were used to express qualitative data. The quantitative data presented nonparametric distribution and were therefore expressed as median + minimum and maximum. To determine normality, the Shapiro-Wilk test was used. The inferential analysis was performed with the Mann-Whitney test, Fisher's exact test and the chi-square test. A significance level of $\alpha=0.05(\mathrm{p}<0.05)$ was adopted.

\section{Results}

Table 2 displays the data of the 42 participants in the study. The PBM group had 20 patients and the placebo group had 22 patients. The samples were balanced with regards to the location of the treated tooth in the maxillary and mandibular arches. Both groups had a larger percentage of female participants.

Table 2: Data on participants of study.

\begin{tabular}{|c|c|c|c|c|c|c|c|}
\hline & \multirow{3}{*}{$\begin{array}{l}\text { Age } \\
\text { Median }\end{array}$} & \multirow[b]{3}{*}{ Minimum } & \multirow[b]{3}{*}{ Maximum } & \multicolumn{2}{|l|}{ Sex } & & \\
\hline & & & & \multirow[b]{2}{*}{$\begin{array}{l}\begin{array}{l}\text { Female } \\
\text { N/\% }\end{array} \\
\end{array}$} & \multirow[b]{2}{*}{$\begin{array}{l}\text { Male } \\
\text { N / \% }\end{array}$} & \multicolumn{2}{|c|}{ Tooth treated } \\
\hline & & & & & & $\begin{array}{l}\text { Maxillary } \\
\text { N/\% }\end{array}$ & $\begin{array}{l}\text { Mandibular } \\
\text { N / \% }\end{array}$ \\
\hline $\begin{array}{l}\text { PBM } \\
\text { group }\end{array}$ & 16 & 11 & 20 & $12 / 60$ & $8 / 40$ & $10 / 50$ & $10 / 50$ \\
\hline $\begin{array}{l}\text { Placebo } \\
\text { group }\end{array}$ & 15 & 11 & 33 & $18 / 90$ & $2 / 10$ & $12 / 55$ & $10 / 45$ \\
\hline
\end{tabular}

Source: Personal archive.

Table 3 displays the results of the analysis of the association between groups (active or placebo) and pain level (VAS). 
Table 3: Analysis of association between pain and group.

\begin{tabular}{|c|c|c|c|c|c|c|c|c|}
\hline & & & No pain & $\begin{array}{l}\text { Mild } \\
\text { pain }\end{array}$ & Moderate pain & $\begin{array}{l}\text { Severe } \\
\text { pain }\end{array}$ & Total & p-value \\
\hline \multirow[t]{8}{*}{ Group } & PBM & $\mathrm{n}$ & 12 & 2 & 6 & $\mathbf{0}$ & 20 & \multirow{6}{*}{$\mathrm{p}=0.033^{*}$} \\
\hline & & $\%$ in group & $60.0 \%$ & $10.0 \%$ & $30.0 \%$ & $0.0 \%$ & $100.0 \%$ & \\
\hline & & $\%$ on scale & $48.0 \%$ & $40.0 \%$ & $85.7 \%$ & $0.0 \%$ & $47.6 \%$ & \\
\hline & & $\%$ of total & $28.6 \%$ & $4.8 \%$ & $14.3 \%$ & $0.0 \%$ & $47.6 \%$ & \\
\hline & \multirow[t]{4}{*}{ Placebo } & $\mathrm{n}$ & 13 & 3 & 1 & 5 & 22 & \\
\hline & & $\%$ in group & $59.1 \%$ & $13.6 \%$ & $4.5 \%$ & $22.7 \%$ & $100.0 \%$ & \\
\hline & & $\%$ on scale & $52.0 \%$ & $60.0 \%$ & $14.3 \%$ & $100.0 \%$ & $52.4 \%$ & \\
\hline & & $\%$ of total & $31.0 \%$ & $7.1 \%$ & $2.4 \%$ & $11.9 \%$ & $52.4 \%$ & \\
\hline
\end{tabular}

*p $<0.05=$ statistically significant difference, chi-squared test. Source: Personal archive.

A significant association was found between group and pain. All participants who reported severe pain were in the placebo group, whereas none of the participants in the laser group reported this level of pain. However, a larger percentage of the participants in the laser group reported feeling moderate pain compared to this same intensity in the placebo group. Regarding reports of mild and no pain, no significant differences were found between the groups. In the analysis of the association between pain and tooth location (maxilla or mandible), no significant difference was found in either the irradiated or placebo group, as shown in Table 4.

Table 4: Analysis of association between pain level and location of tooth according to study groups.

\begin{tabular}{|c|c|c|c|c|c|c|c|}
\hline Group & & Region & & Maxillary & Mandibular & & p-value \\
\hline \multirow[t]{12}{*}{ PBM } & \multirow[t]{12}{*}{ Pain scale } & \multirow[t]{4}{*}{ No pain } & $\mathrm{n}$ & 6 & 6 & 12 & \multirow{12}{*}{$\mathrm{p}=0.264$} \\
\hline & & & $\%$ on scale & $50.0 \%$ & $50.0 \%$ & $100.0 \%$ & \\
\hline & & & $\%$ in region & $60.0 \%$ & $60.0 \%$ & $60.0 \%$ & \\
\hline & & & $\%$ of total & $30.0 \%$ & $30.0 \%$ & $60.0 \%$ & \\
\hline & & \multirow[t]{4}{*}{ Mild pain } & $\mathrm{n}$ & 2 & 0 & 2 & \\
\hline & & & $\%$ on scale & $100.0 \%$ & $0.0 \%$ & $100.0 \%$ & \\
\hline & & & $\%$ in region & $20.0 \%$ & $0.0 \%$ & $10.0 \%$ & \\
\hline & & & $\%$ of total & $10.0 \%$ & $0.0 \%$ & $10.0 \%$ & \\
\hline & & \multirow[t]{4}{*}{ Moderate pain } & $\mathrm{n}$ & 2 & 4 & 6 & \\
\hline & & & $\%$ on scale & $33.3 \%$ & $66.7 \%$ & $100.0 \%$ & \\
\hline & & & $\%$ in region & $20.0 \%$ & $40.0 \%$ & $30.0 \%$ & \\
\hline & & & $\%$ of total & $10.0 \%$ & $20.0 \%$ & $30.0 \%$ & \\
\hline \multirow[t]{16}{*}{ Placebo } & \multirow[t]{16}{*}{ Pain scale } & \multirow[t]{4}{*}{ No pain } & $\mathrm{n}$ & 7 & 6 & 13 & \multirow{16}{*}{$\mathrm{p}=0.264$} \\
\hline & & & $\%$ on scale & $53.8 \%$ & $46.2 \%$ & $100.0 \%$ & \\
\hline & & & $\%$ in region & $58.3 \%$ & $60.0 \%$ & $59.1 \%$ & \\
\hline & & & $\%$ of total & $31.8 \%$ & $27.3 \%$ & $59.1 \%$ & \\
\hline & & \multirow[t]{4}{*}{ Mild pain } & $\mathrm{n}$ & 2 & 1 & 3 & \\
\hline & & & $\%$ on scale & $66.7 \%$ & $33.3 \%$ & $100.0 \%$ & \\
\hline & & & $\%$ in region & $16.7 \%$ & $10.0 \%$ & $13.6 \%$ & \\
\hline & & & $\%$ of total & $9.1 \%$ & $4.5 \%$ & $13.6 \%$ & \\
\hline & & \multirow[t]{4}{*}{ Moderate pain } & $\mathrm{n}$ & 0 & 1 & 1 & \\
\hline & & & $\%$ on scale & $0.0 \%$ & $100.0 \%$ & $100.0 \%$ & \\
\hline & & & $\%$ in region & $0.0 \%$ & $10.0 \%$ & $4.5 \%$ & \\
\hline & & & $\%$ of total & $0.0 \%$ & $4.5 \%$ & $4.5 \%$ & \\
\hline & & \multirow[t]{4}{*}{ Severe pain } & $\mathrm{n}$ & 3 & 2 & 5 & \\
\hline & & & $\%$ on scale & $60.0 \%$ & $40.0 \%$ & $100.0 \%$ & \\
\hline & & & $\%$ in region & $25.0 \%$ & $20.0 \%$ & $22.7 \%$ & \\
\hline & & & $\%$ of total & $13.6 \%$ & $9.1 \%$ & $22.7 \%$ & \\
\hline
\end{tabular}

$* \mathrm{p}<0.05=$ statistically significant difference, chi-squared test. Source: Personal archive 
The analysis according to sex revealed a stronger association between pain and the female sex in both groups, as displayed in Table 5.

Table 5: Analysis of association between pain level and sex according to study groups.

\begin{tabular}{|c|c|c|c|c|c|c|c|}
\hline Group & & Sex & & Female & Male & Total & p-value \\
\hline \multirow[t]{12}{*}{$\overline{\text { PBM }}$} & \multirow[t]{12}{*}{ Pain scale } & \multirow[t]{4}{*}{ No pain } & $\mathrm{n}$ & 4 & 8 & 12 & \multirow{12}{*}{$\mathrm{p}=0.012 *$} \\
\hline & & & $\%$ on scale & $33.3 \%$ & $66.7 \%$ & $100.0 \%$ & \\
\hline & & & $\%$ in sex & $33.3 \%$ & $100.0 \%$ & $60.0 \%$ & \\
\hline & & & $\%$ of total & $20.0 \%$ & $40.0 \%$ & $60.0 \%$ & \\
\hline & & \multirow[t]{4}{*}{ Mild pain } & $\mathrm{n}$ & 2 & 0 & 2 & \\
\hline & & & $\%$ on scale & $100.0 \%$ & $0.0 \%$ & $100.0 \%$ & \\
\hline & & & $\%$ in sex & $16.7 \%$ & $0.0 \%$ & $10.0 \%$ & \\
\hline & & & $\%$ of total & $10.0 \%$ & $0.0 \%$ & $10.0 \%$ & \\
\hline & & \multirow[t]{4}{*}{ Moderate pain } & $\mathrm{n}$ & 6 & 0 & 6 & \\
\hline & & & $\%$ on scale & $100.0 \%$ & $0.0 \%$ & $100.0 \%$ & \\
\hline & & & $\%$ in sex & $50.0 \%$ & $0.0 \%$ & $30.0 \%$ & \\
\hline & & & $\%$ of total & $30.0 \%$ & $0.0 \%$ & $30.0 \%$ & \\
\hline \multirow[t]{16}{*}{ Placebo } & \multirow[t]{16}{*}{ Pain scale } & \multirow[t]{4}{*}{ No pain } & $\mathrm{n}$ & 13 & 0 & 13 & \multirow{16}{*}{$\mathrm{p}=0.006^{*}$} \\
\hline & & & $\%$ on scale & $100.0 \%$ & $0.0 \%$ & $100.0 \%$ & \\
\hline & & & $\%$ in sex & $65.0 \%$ & $0.0 \%$ & $59.1 \%$ & \\
\hline & & & $\%$ of total & $59.1 \%$ & $0.0 \%$ & $59.1 \%$ & \\
\hline & & \multirow[t]{4}{*}{ Mild pain } & $\mathrm{n}$ & 3 & 0 & 3 & \\
\hline & & & $\%$ on scale & $100.0 \%$ & $0.0 \%$ & $100.0 \%$ & \\
\hline & & & $\%$ in sex & $15.0 \%$ & $0.0 \%$ & $13.6 \%$ & \\
\hline & & & $\%$ of total & $13.6 \%$ & $0.0 \%$ & $13.6 \%$ & \\
\hline & & \multirow[t]{4}{*}{ Moderate pain } & $\mathrm{n}$ & 0 & 1 & 1 & \\
\hline & & & $\%$ on scale & $0.0 \%$ & $100.0 \%$ & $100.0 \%$ & \\
\hline & & & $\%$ in sex & $0.0 \%$ & $50.0 \%$ & $4.5 \%$ & \\
\hline & & & $\%$ of total & $0.0 \%$ & $4.5 \%$ & $4.5 \%$ & \\
\hline & & \multirow[t]{4}{*}{ Severe pain } & $\mathrm{n}$ & 4 & 1 & 5 & \\
\hline & & & $\%$ on scale & $80.0 \%$ & $20.0 \%$ & $100.0 \%$ & \\
\hline & & & $\%$ in sex & $20.0 \%$ & $50.0 \%$ & $22.7 \%$ & \\
\hline & & & $\%$ of total & $18.2 \%$ & $4.5 \%$ & $22.7 \%$ & \\
\hline
\end{tabular}

*p $<0.05=$ statistically significant difference, chi-squared test. Source: Personal archive.

Table 6 shows the concentrations of IL-1 $\beta$ in the PBM and placebo groups. No significant difference between treatments $(p=0.971)$ or times $(p=0.637)$ and no significant interactions $(p=0.676)$ were revealed in the two-way repeatedmeasures analysis of variance. 
Table 6: Concentrations of the cytokine IL-1 $\beta$ in the PBM and placebo groups.

\section{Mean IL-1B}

Immediately after placement of separators

\begin{tabular}{lr|r|r} 
Group & Mean & N & \multicolumn{1}{c}{ Deviation } \\
\hline PBM & 147.96 & 14 & 128.13 \\
\hline Placebo & 97.84 & 10 & 76.43 \\
\hline Total & 127.07 & 24 & 110.46 \\
\hline
\end{tabular}

Source: Personal archive.

\section{Discussion}

The placement of elastomeric separators generates space between the teeth and banding molars is part of routine orthodontic treatment. This process causes the movement of the adjacent teeth due to close interproximal contacts as well as the release of biochemical mediators in the gingival sulcus. Average band thickness is $0.16 \mathrm{~mm}$, requiring a separation of 0.25 $\mathrm{mm}$. Separation methods should involve easy placement with little or no discomfort. Elastomeric separators are more efficient than other separators, but generate a higher level of pain (Qamruddin, 2016; Tripathi, 2019). Pain involved in the placement of separators affects functions such as chewing and the eating pattern and the discomfort may lead to a need for medication (Sousa, 2014; Marini, 2015; Dalaie, 2015; Tripathi, 2019).

Pain can vary with several factors, such as age, sex, pain threshold, magnitude of the applied force, emotional state, the presence of stress, cultural discrepancies and previous trauma. The feeling of pain is part of an inflammatory response resulting in the liberation of chemical mediators, like prostaglandins, histamine, bradykinins, serotonin and substance $\mathrm{P}$ as well as cytokines, such as interleukin-1 beta (IL-1 $\beta$ ), making the periodontal ligament sensitive and provoking a hyperalgesic response (Abtahi, 2013; Ren, 2015; Almallah, 2016; Farias, 2016). According to Dominguez et al. (2015), results from previous studies indicate that greater dental pain intensity is experienced soon after the onset of treatment and is associated with the increase in the level of these mediators.

Medications reported to effective at controlling pain include ibuprofen, paracetamol/acetaminophen, sodium naproxen, aspirin, meloxicam, etoricoxib, piroxicam and tenoxicam, all of which have side effects. Alternative therapies without side effects are also described for pain, for instance, physiotherapeutic methods, gum and a viscoelastic plate (Farganegan, 2012; Bayani, 2016; Nadhreen, 2019; Topolski, 2018). Farzanegan et al. (2012), and Bayani et al. (2016), found that chewing gum and viscoelastic plates can replace ibuprofen.

Recent studies have shown that photobiomodulation is favorable to the reduction in pain sensitivity due to its antiinflammatory and photobiomodulating action. Laser irradiation offers advantages, such as hemostasis, the absence of mechanical contact, regenerative capacity and a reduction in bacterial cells at the application site (Nadhreen, 2019).

A study involving rats submitted to palatal expansion reported that the PBM group continued gaining weight more easily when compared to the non-irradiated control group due to the more effective control of pain with PBM (Artés-Ribas, 2013). Kim et al. (2013); Eslamian et al. (2013); Marini et al. (2015); and Farias et al. (2016) and found that the administration of PBM after the placement of separators was effective at controlling pain in the first three days, with an accentuated difference between the treatment and control groups. Farias et al. (2016) and Eslamian et al. (2013) found positive results using infrared laser at a wavelength of $810 \mathrm{~nm}$ regarding the reduction in pain respectively with a single dose (three points on the vestibular face for 15 seconds each) and with 10 doses repeated after 24 hours. Almallah et al. (2016) checked the effect of infrared laser comparing a protocol with a single application immediately after the placement of the separators and another 
protocol with two applications (immediately after placement and after 24 hours). They found that PBM was effective at pain reduction, corroborating with our results (in which no patient in the PBM presented severe pain), with no significant difference between one and two sessions.

Sobouti et al. (2015), also reported a positive effect on the reduction in pain using red laser during the traction of maxillary canines. However, Dalaie et al. (2015), and Cronshaw et al. (2019), found no significant differences in pain during orthodontic movement with the administration of infrared laser. Bayani et al. (2016), compared red and infrared PBM to bite plates and ibuprofen and concluded that infrared laser was more effective at controlling pain. Based on information compiled from previous articles, Sousa et al. (2014), concluded that pain is inhibited with both red and infrared wavelength applying energy between 1 to $2 \mathrm{~J}$ and alternating powers, points and the quantity of energy. Lee et al. (2018), reported the use of red laser for the regulation of pro-inflammatory cytokines, which could be of considerable use in periodontal therapy.

PBM is a quickly growing modality for stimulating healing, enhancing tissue regeneration and reducing both pain and inflammation. PBM has no reported side effects and no long-term adaptation to treatment has been shown. Infrared laser has clinical advantages for pain control, such as deeper penetration (Shi, 2015; de Sousa, 2018; Cronshaw, 2019). According to Ren et al. (2008), the results of studies that investigate pain reduction in orthodontics with the application of laser depend on three main factors: individual variation, the methods employed in the study and the laser parameters. A difference in IL- $1 \beta$ was expected, since this cytokine is present in situations of pain and inflammation (Ren, 2015). However, no difference between groups was found. Future studies should test different collection times.

PBM is also being explored in other topics on Orthodontics. Its effect on on accelerating orthodontic tooth movement (Dominguez, 2020; Li, 2021), on the prevention of enamel demineralization (Paulos, 2017), and even its capacity to enhance the efficiency of dental alignment (Caccianiga, 2017; Lo Giudice, 2020) have been researched. Our study showed its efficacy at preventing severe pain during the use of elastomeric separators. This shows that PBM is a therapy that is being more and more encouraged in this particular field of Dentistry.

\section{Conclusion}

A significant difference in pain sensitivity was found when PBM was administered after the positioning of elastomeric separators. During the experiment, only the placebo group reported feeling severe pain, whereas none of the individuals in the PBM group reported this degree of pain. The present findings suggest that the application of infrared laser on the dental mucosa has an analgesic, preventive, photomodulating effect on the pain experienced after placing elastomeric separators. Thus, PBM may be a useful tool in orthodontic treatment.

\section{References}

Abtahi, S. M., Mousavi, S. A., Shafaee, H., \& Tanbakuchi, B. (2013). Effect of low-level laser therapy on dental pain induced by separator force in orthodontic treatment. Dental research journal, 10(5), 647-651.

Almallah, M. M., Almahdi, W. H., \& Hajeer, M. Y. (2016). Evaluation of Low Level Laser Therapy on Pain Perception Following Orthodontic Elastomeric Separation: A Randomized Controlled Trial. Journal of clinical and diagnostic research: JCDR, 10(11), ZC23-ZC28. https://doi.org/10.7860/JCDR/2016/22813.8804.

Artés-Ribas, M., Arnabat-Dominguez, J. \& Puigdollers, A. (2013). Analgesic effect of a low-level laser therapy (830 nm) in early orthodontic treatment. Lasers in Medical Science, 28, 335-341. https://doi.org/10.1007/s10103-012-1135-y.

Basso, F.G., Soares, D.G., de Souza Costa, C.A., Hebling J. (2016). Low-level laser therapy in 3D cell culture model using gingival fibroblasts. Lasers in Medical Science, 31, 973-978. https://doi.org/10.1007/s10103-016-1945-4.

Bayani, S., Rostami, S., Ahrari, F., \& Saeedipouya, I. (2016). A randomized clinical trial comparing the efficacy of bite wafer and low level laser therapy in reducing pain following initial arch wire placement. Laser therapy, 25(2), 121-129. https://doi.org/10.5978/islsm.16-OR-10. 
Caccianiga, G., Paiusco, A., Perillo, L., Nucera, R., Pinsino, A., Maddalone, M., Cordasco, G., Lo Giudice, A. (2017). Does Low-Level Laser Therapy Enhance the Efficiency of Orthodontic Dental Alignment? Results from a Randomized Pilot Study. Photomedicine Laser Surgery, 35(8), 421-426. 10.1089/pho.2016.4215.

Cronshaw, M., Parker, S., Anagnostaki, E., Lynch, E. (2019). Systematic Review of Orthodontic Treatment Management with Photobiomodulation Therapy. Photobiomodulation, Photomedicine, and Laser Surgery, 37(2), 862-868 10.1089/photob.2019.4702.

Dalaie, K., Hamedi, R., Kharazifard, M. J., Mahdian, M., \& Bayat, M. (2015). Effect of Low-Level Laser Therapy on Orthodontic Tooth Movement: A Clinical Investigation. Journal of dentistry (Tehran, Iran), 12(4), 249-256.

de Sousa, M., Kawakubo, M., Ferraresi, C., Kaippert, B., Yoshimura, E. M., \& Hamblin, M. R. (2018). Pain management using photobiomodulation: Mechanisms, location, and repeatability quantified by pain threshold and neural biomarkers in mice. Journal of biophotonics, 11(7), e201700370. https://doi.org/10.1002/jbio.201700370.

Dalaie, K., Hamedi, R., Kharazifard, M. J., Mahdian, M., \& Bayat, M. (2015). Effect of Low-Level Laser Therapy on Orthodontic Tooth Movement: A Clinical Investigation. Journal of dentistry (Tehran, Iran), 12(4), 249-256.

Domínguez, A., Gómez, C. \& Palma, J. C. (2015). Effects of low-level laser therapy on orthodontics: rate of tooth movement, pain, and release of RANKL and OPG in GCF. Lasers in Medical Sciences, 30, 915-923. https://doi.org/10.1007/s10103-013-1508-x.

Domínguez Camacho, A., Montoya Guzmán, D., Velásquez Cujar, S. A. (2020). Effective Wavelength Range in Photobiomodulation for Tooth Movement Acceleration in Orthodontics: A Systematic Review. Photobiomodulation, Photomedicine and Laser Surgery, 38(10), 581-590. 10.1089/photob.2020.4814.

Eslamian, Ladan \& Borzabadi-Farahani, Ali \& Hassanzadeh-Azhiri, Aidin \& Badiee, Mohammad \& Fekrazad, Reza. (2014). The effect of 810-nm low-level laser therapy on pain caused by orthodontic elastomeric separators. Lasers in medical science, 29, 559-564. 10.1007/s10103-012-1258-1.

Farias, R. D., Closs, L. Q., \& Miguens, S. A., Jr (2016). Evaluation of the use of low-level laser therapy in pain control in orthodontic patients: A randomized split-mouth clinical trial. The Angle orthodontist, 86(2), 193-198. https://doi.org/10.2319/122214-933.1.

Farzanegan, F., Zebarjad, S.M., Alizadeh, S., Ahrari, F. (2012). Pain reduction after initial archwire placement in orthodontic patients: A randomized clinical Trial. American Journal of Orthodontics and Dentofacial Orthopedics, 141(2), 169-73. 10.1016/j.ajodo.2011.06.042.

Huang, T. H., Liu, S. L., Chen, C. L., Shie, M. Y., \& Kao, C. T. (2013). Low-level laser effects on simulated orthodontic tension side periodontal ligament cells. Photomedicine and laser surgery, 31(2), 72-77. https://doi.org/10.1089/pho.2012.3359.

Kim, W.T., Bayome, M., Park, J.B., Park, J.H., Baek, S.H., Kook, Y.A. (2013). Effect of frequent laser irradiation on orthodontic pain. A single-blind randomized clinical Trial. Angle Orthodontics, 83(4), 611-6. 10.2319/082012-665.1.

Lee, J. H., Chiang, M. H., Chen, P. H., Ho, M. L., Lee, H. E., \& Wang, Y. H. (2018). Anti-inflammatory effects of low-level laser therapy on human periodontal ligament cells: in vitro study. Lasers in medical science, 33(3), 469-477. https://doi.org/10.1007/s10103-017-2376-6.

Li, J., Ge, X., Guan, H., Jia, L., Chang, W., Ma, W. (2021). The Effectiveness of Photobiomodulation on Accelerating Tooth Movement in Orthodontics: A Systematic Review and Meta-Analysis. Photobiomodulation, Photomedicine and Laser Surgery, 39(4), 232-244. 10.1089/photob.2020.4954.

Lo Giudice, A., Nucera, R., Leonardi, R., Paiusco, A., Baldoni, M., \& Caccianiga, G. (2020). A Comparative Assessment of the Efficiency of Orthodontic Treatment With and Without Photobiomodulation During Mandibular Decrowding in Young Subjects: A Single-Center, Single-Blind Randomized Controlled Trial. Photobiomodulation, photomedicine, and laser surgery, 38(5), 272-279. https://doi.org/10.1089/photob.2019.4747.

Marini, I., Bartolucci, M. L., Bortolotti, F., Innocenti, G., Gatto, M. R., Alessandri Bonetti, G. (2015). The effect of diode superpulsed lowlevel laser therapy on experimental orthodontic pain caused by elastomeric separators: a randomized controlled clinical trial. Lasers in medical science, 30(1), 35-41. $10.1007 / \mathrm{s} 10103-013-1345-\mathrm{y}$.

Mohammad-Hoseyni, A., Pirmoradian-Najafabadi, M., Ashnagar, S., Nokhbatolfoghahaei, H., Fekrazad, R. (2015). Effect ofLow Level Laser Therapy on Pain Reduction After Midpalatal Expansion in Rats. J Dent (Tehran), 12(9), 655-61.

Murakami-Malaquias-Silva, F., Rosa, E. P., Almeida, P. A., Schalch, T. O., Tenis, C. A., Negreiros, R. M., Horliana, R. F., Garcez, A. S., Fernandes, M., Tortamano, A., Motta, L. J., Bussadori, S. K., \& Horliana, A. (2020). Evaluation of the effects of photobiomodulation on orthodontic movement of molar verticalization with mini-implant: A randomized double-blind protocol study. Medicine, 99(13), e19430. https://doi.org/10.1097/MD.0000000000019430.

Nadhreen, A. A., Alamoudi, N. M., Elkhodary, H. M. (2019). Low-level Laser Therapy in Dentistry: Extra-oral Applications. Nigerian Journal of Clinical Practice, 22(10), 1313-1318.

Paulos, R. S., Seino, P. Y., Fukushima, K. A., Marques, M. M., de Almeida, F. C. S., Ramalho, K. M., de Freitas, P. M., Brugnera, A Junior., Moreira, M. S. (2017). Effect of Nd:YAG and CO2 Laser Irradiation on Prevention of Enamel Demineralization in Orthodontics: In Vitro Study. Photomedicine and Laser Surgery, 35(5), 282-286. 10.1089/pho.2016.4235.

Qamruddin, I., Alam, M. K., Fida, M., Khan, A. G. (2016). Effect of a single dose of low-level laser therapy on spontaneous and chewing pain caused by elastomeric separators. American Journal of Orthodontics and Dentofacial Orthopedics, 149(1), $62-66$. 10.1016/j.ajodo.2015.06.024.

Ren, K., Torres, R. (2009). Role of interleukin 1beta during pain and inflammation. Brain Research, 60(1), 57-64.

Ren, C., McGrath, C., Yang, Y. (2015). The effectiveness of low-level diode laser therapy on orthodontic pain management: a systematic review and metaanalysis. Lasers in medical science, 30(7), 1881-93. 10.1007/s10103-015-1743-4. 
Research, Society and Development, v. 11, n. 2, e50911225979, 2022

(CC BY 4.0) | ISSN 2525-3409 | DOI: http://dx.doi.org/10.33448/rsd-v11i2.25979

Shi, Q., Yang, S., Jia, F. and Xu, J. (2015). Does low level laser therapy relieve the pain caused by the placementof the orthodontic separators? - A meta analysis. Head \& Face Medicine 11:28.

Sobouti, F., Khatami, M., Chiniforush, N., Rakhshan, V., \& Shariati, M. (2015). Effect of single-dose low-level helium-neon laser irradiation on orthodontic pain: a split-mouth single-blind placebo-controlled randomized clinical trial. Progress in orthodontics, 16, 32. https://doi.org/10.1186/s40510-015-0102-0.

Sousa, M. V., Pinzan, A., Consolaro, A., Henriques, J. F., de Freitas, M. R. (2014). Systematic Literature Review: Influence of Low-Level Laser on Orthodontic Movement and Pain Control in Humans. Photomedicine and Laser Surgery, 32(11), 592-9. 10.1089/pho.2014.3789.

Topolski, F., Moro, A., Correr, G. M., \& Schimim, S. C. (2018). Optimal management of orthodontic pain. Journal of pain research, 11, 589-598. https://doi.org/10.2147/JPR.S127945.

Tripathi, T., Singh, N., Rai, P., \& Khanna, N. (2019). Separation and pain perception of Elastomeric, Kesling and Kansal separators. Dental press journal of orthodontics, 24(2), 42-48. https://doi.org/10.1590/2177-6709.24.2.042-048.oar. 